\title{
NOVITATES RIO MUNIS 1. A NEW ENDEMIC SCAPHOPETALUM (MALVACEAE) FROM MOUNT MITRA, EQUATORIAL GUINEA
}

\author{
MIGUEL E. LEAL \\ Missouri Botanical Garden, P.O. Box 299, St Louis, Missouri 63166, USA \\ e-mail: Miguel.Leal@mobot.org
}

\begin{abstract}
SUMMARY
A new species of Scaphopetalum from Monte Mitra is described.

Key words: Malvaceae, Scaphopetalum, Central Africa, Equatorial Guinea, taxonomy.

During a biodiversity assessment of the Monte Mitra forest in October 2005 a Scaphopetalum with white flowers was encountered. This is exceptional as all other Scaphopetalum species have either yellow or dark purple petals (Germain, 1963; Hallé, 1968; Schumann, 1900; Leal, in prep). This new Scaphopetalum is also the first endemic species found on the mainland of Equatorial Guinea (Río Muní). As this species was found in Monte Alen National Park, part of a national system of protected areas created by President Teodoro Obiang Nguema, it is a good opportunity to recognize the president's conservation efforts by commemorating him.
\end{abstract}

Scaphopetalum obiangianum M.E. Leal, spec. nov. - Fig. 1

Haec species eum excipio intra Scaphopetalo propter floribus ablis suis et ceterum fructus brevi subconatus quinque costatis. - Typus: M.E. Leal 846 (holo MO; iso BATA, WAG), Equatorial Guinea, Monte Mitra, 5 October 2005.

Small shrub 20-150 cm tall. Petiole 3-5 mm. Leaves obovate, glabrous and shiny, $7.5-13$ by $2.5-5.5 \mathrm{~cm}$, base rounded, apex shortly caudate. Inflorescence raminascent, few-flowered cymes, peduncle 3-4 mm long, 1-5 flowers, pedicel 2-3 cm. Sepals 9-10 by 4-3 mm narrowly ovate, hairy on the inside of the tip. Petals hooded, whitish transparent and ribbed, $0.8-1$ by $0.5-0.7 \mathrm{~cm}$, apex with three short slips. Stamens fused in vase-like tube, $1 \mathrm{~cm}$ diam. and $0.5 \mathrm{~cm}$ high, with 5 sharply angled lobes, each lobe has a red ray, anthers inserted on the lobes. Ovary 5-lobed, style $1 \mathrm{~mm}$ long. Capsule glabrous, $1.5-2$ by $0.6-0.9 \mathrm{~cm}$, with 5 sharply angled ridges. Seeds $2 \mathrm{~mm}$, adorned with a brown aril.

Distribution - Equatorial Guinea, at the base of Monte Mitra.

Habitat - Understorey of (submontane) rain forest at an altitude of $700 \mathrm{~m}$.

Note - Equatorial Guinea is the only country in central Africa without a national flora. Some believe that such a reference book is not needed arguing that the plants of Equatorial Guinea are completely a subset of those found in Cameroon and Gabon 
Fig. 1. Scaphopetalum obiangianum M.E. Leal. a. Habit; b. flower; c. capsule (a-c: Leal 846, MO, WAG).

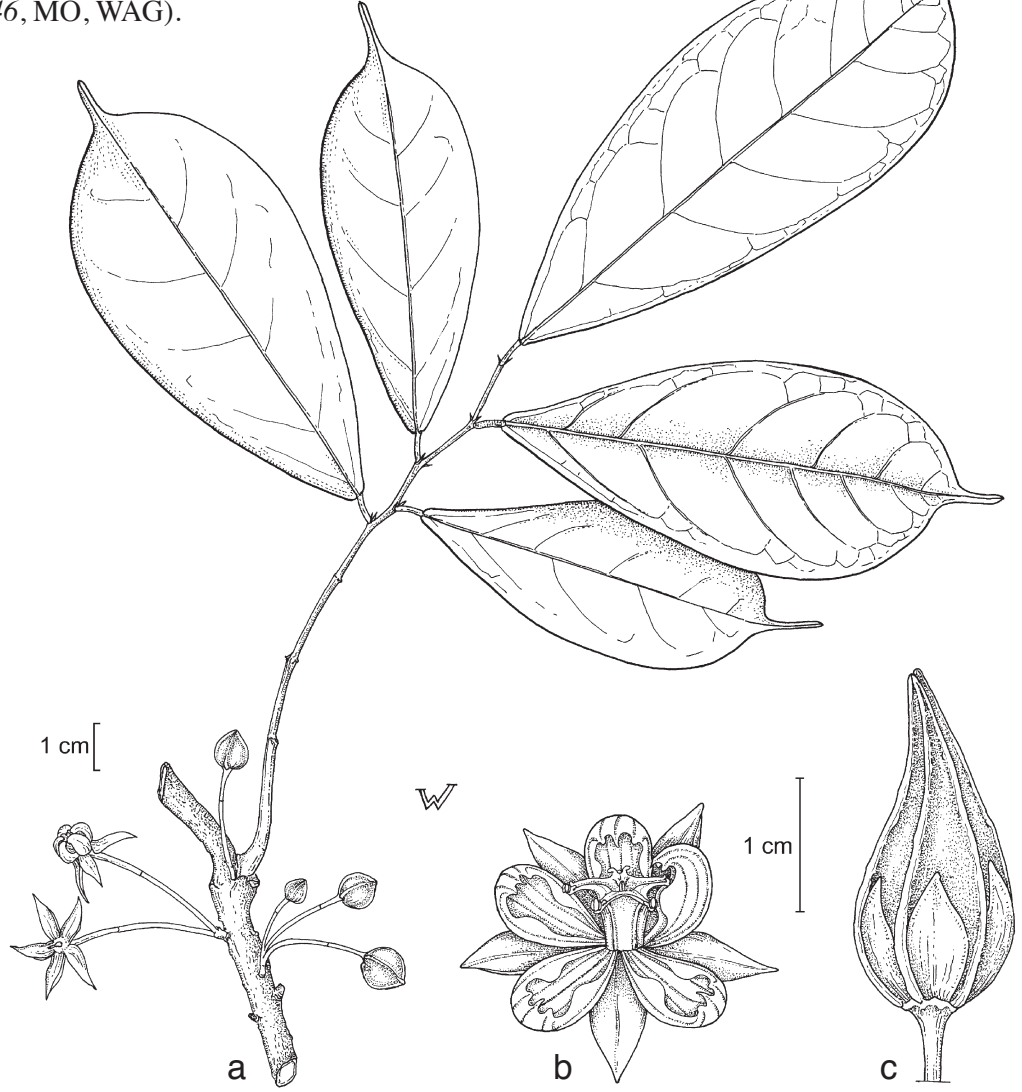

and adequately covered by the national floras of those countries. This new species from mainland Río Muní suggests that Equatorial Guinea's flora may include many endemic contributions. The new find also demonstrates our poor knowledge of Equatorial Guinea's flora and the need for more botanical field research.

\section{ACKNOWLEDGEMENTS}

Fieldwork was funded by the Central Africa Regional Program of the Environment (CARPE) in collaboration with Conservation International (CI) and Equatorial Guinea's Instituto Nacional de Desarrollo Forestal (INDEFOR).

\section{REFERENCES}

Germain, R. 1963. Sterculiaceae. Flore du Congo, du Rwanda et du Burundi 10: 212-219.

Hallé, N. 1968. Sterculiaceae. Flore du Gabon 15: 115-125.

Leal, M.E. In prep. A revision of the genus Scaphopetalum (Malvaceae).

Schumann, K. 1900. Sterculiaceae africanae. In: A. Engler (ed.), Monogr. Afrik. Pflanzen-Fam. 6: 90-92. Leipzig. 